\title{
I Have a Ph.D.! Now What? A Program to Prepare Engineering Ph.D.'s and Postdoctoral Fellows for Diverse Career Options
}

\section{Teresa J. Didiano, University of Toronto}

Teresa Didiano is the Special Programs Coordinator at the Troost Institute for Leadership Education in Engineering at the University of Toronto. She develops and coordinates leadership programs for undergraduate students, graduate students, and engineering professionals. Teresa has an HBSc and MSc from the University of Toronto, and Life Skills Coaching Certification from George Brown College.

\section{Ms. Lydia Wilkinson, University of Toronto}

Lydia Wilkinson is a lecturer in the Engineering Communication Program at the University of Toronto, where she coordinates communication in Chemical Engineering, and teaches core communication courses at the undergraduate and graduate level. Lydia's current research investigates interdisciplinary skills transfer with a specific focus on humanities integration for engineers.

\section{Dr. Jonathan Turner, University of Toronto}

Jonathan Turner is a Career Educator who specializes in working with graduate students and postdoctoral fellows. He co-founded a Canadian community of practice for career and professional development practitioners, and as an executive he launched a monthly article series, effected changes to a national survey of graduate and professional students, and has increased the sustainability and longevity of that community.

Mr. Mark Franklin, University of Toronto \& OneLifeTools

Mark Franklin is the award-winning practice leader of CareerCycles, a career management social enterprise based in Toronto, and co-founder of OneLifeTools. Mark and a team of Associates have enriched the career wellbeing of 4000+ clients individually and in organizations. Mark holds a Bachelor of Applied Science in Industrial Engineering, a Master of Education in Counselling Psychology, and a P.Eng. license. In 2015, he received the Stu Conger Award for Leadership in Career Development. In his earlier engineering career, Mark consulted with hundreds of organizations as a technology manager, then management consultant with KPMG. Changing careers, Mark led student services initiatives in two of Canada's largest universities, now teaches a for-credit career management course at University of Toronto and applies system thinking and engineering problem solving to create scalable, gamified and evidence-based career management tools. Mark hosts the Career Buzz radio show and podcast where he's interviewed hundreds of guests about insights and turning points in their career stories.

\section{Prof. Jason H. Anderson, University of Toronto}

Jason Anderson (http://janders.eecg.toronto.edu/) is Professor and Associate Chair, Research, with the Dept. of Electrical and Computer Engineering, University of Toronto, and holds the Jeffrey Skoll Endowed Chair. He joined the FPGA Implementation Tools Group, Xilinx, Inc., San Jose, CA, USA, in 1997, where he was involved in placement, routing, and synthesis. He became a Principal Engineer at Xilinx in 2007 and joined the university in 2008. His research interests are all aspects of tools, architectures, and circuits for FPGAs. He has co-authored over 90 peer-reviewed research publications, 4 book chapters, holds 29 U.S. patents, and was Program Co-Chair for FPL 2016, Program Chair for ACM FPGA 2017, and is General Chair for ACM FPGA 2018. He is Co-Founder and Chief Scientific Advisor of LegUp Computing Inc.

\section{Prof. Markus Bussmann, University of Toronto}

Dr. Bussmann is Professor and Chair of the Department of Mechanical \& Industrial Engineering at the University of Toronto, and formerly, Vice-Dean, Graduate for the Faculty of Applied Science \& Engineering. In the latter role he was involved with the initial development of the OPTIONS (Opportunities for PhDs: Transitions, Industry Options, Networking and Skills) program for engineering PhDs and postdoctoral fellows at the UofT. 


\section{Dr. Doug Reeve, University of Toronto}

Dr. Reeve is the founding Director of the Institute for Leadership Education in Engineering (ILead) (20102018) at the University of Toronto. After a lengthy career as a consulting engineer he made development of personal capability central to his work with engineering students, undergraduate and graduate. In 2002 he established Leaders of Tomorrow, a student leadership development program that led to the establishment of ILead in 2010. In 2017, he was part of the team that developed the OPTIONS Program (Opportunities for PhDs: Transitions, Industry Options, Networking and Skills) for engineering PhD students interested in careers outside the academy. He is a Professor in the Department of Chemical Engineering and Applied Chemistry.

\section{Prof. Julie Audet P.Eng., University of Toronto}

Professor Audet is the Vice-Dean Graduate Studies in the Faculty of Applied Science and Engineering of the University of Toronto (2017- ). She served as the Associate Director, Graduate Studies for the Institute of Biomaterials and Biomedical Engineering (IBBME) from 2012 to 2017. In recent years, Dr. Audet has worked on the development of a new graduate program Master's of Engineering in Biomedical Engineering, at IBBME that is focused on biomedical devices. The new M.Eng is now also offered to MD students in the Faculty of Medicine. This program fulfills an unmet need in expertise in biomedical device development in the Canadian Industry and has attracted students across multiple Faculties and Universities. Dr. Audet has contributed to the development of Graduate Supervision Guidelines in the School of Graduate Studies. Professor Audet has been an instructor and coordinator of several undergraduate and graduate courses covering Statistical Design of Experiments for Bioprocess Optimization, Biostatistics and Statistical discovery techniques for biomedical researchers, all of which are closely related to her research interests, in particular the development of biological search algorithms and their applications in stem and progenitor cell manufacturing processes. 


\section{Have a PhD! Now What? A Program to Prepare Engineering PhDs and Post-doctoral Fellows for Diverse Career Options}

\section{Introduction}

Traditional engineering doctoral programs prepare students for the professoriate; however, very few go on to secure tenure-track, faculty positions [1, 2]. In Canada, 14.7\% of engineering PhD graduates (including architecture and related technologies) are employed as full-time university professors [1]. The majority find employment in a wide range of sectors including research and development, manufacturing, health care, and government $[2,3]$. In comparison to other fields of study, engineering $\mathrm{PhDs}$ are more likely to be employed outside the academy $[1,4]$. PhDs are not pursuing academic jobs due to a lack of tenure-track positions, changing research interests, lucrative opportunities in industry, commercialization of research, and more $[5,6]$. Thus, the linear, career model of PhD to post-doctoral fellow to professor is clearly out of step with today's realities. PhDs have been departing from this model to follow diverse career pathways and make contributions to the scientific community, industry, and broader society beyond the academy. As the number of PhDs awarded outpace academic positions [7], policy makers, faculty, educators and students are bringing attention to the need for the professional preparation of engineering $\mathrm{PhDs}[8,9]$.

Institutions are beginning to respond to this need by introducing career development and professional skills training into engineering graduate curricular and co-curricular experiences [9, 10]. For example, the Faculty of Applied Science and Engineering (FASE) at the University of Toronto (U of T), in partnership with seven departmental and two Faculty-wide student organizations, hosts an engineering-specific career fair for graduate students [11]. The University of Alberta's Faculty of Engineering requires graduate students complete a minimum of eight hours of professional development including generating an individual development plan [12]. U of $\mathrm{T}$ and the University of British Columbia tracked employment outcomes of all $\mathrm{PhD}$ graduates including engineering alumni [3, 13]. Queen's University produced Grad Maps to help graduate students, including those in the Faculty of Engineering and Applied Science, navigate their academic milestones and professional development [14]. These examples highlight the variety of initiatives that institutions have undertaken to prepare engineering $\mathrm{PhDs}$ for career options beyond the academy. Doctoral programs provide a transferable skill set beyond disciplinespecific knowledge that is valuable for many careers, for example, communication, project management, and innovative thinking $[15,16]$. It is imperative for engineering educators to continue to grow and sustain opportunities to support PhDs as they navigate the school-to-work transition.

One opportunity, and the focus of this paper, is multi-session, cohort programs that provide a high intensity learning experience with a community of people [17-19]. For example, The Department of Biochemistry at U of T offers a six-session, Graduate Professional Development course for 20 students that covers topics in reflection through an individual development plan, networking, and strategic communications. Students participate in a one-on-one with the course instructor and are given assignments such as writing a lay summary of their research, developing a resumé and cover letter, and cold contacting an alumni [17]. Similarly, the Skaggs Graduate School of Chemical and Biological Sciences at The Scripps Research Institute offers a sevensession Effective Career Planning for PhDs course for ten to 15 participants. Students create an 
individual development plan poster, present on two career options of interest, listen to a panel of industry professionals, and learn networking techniques (e.g., informational interview questions, elevator pitch) [18]. Likewise, The Center for Biomedical Career Development at the University of Massachusetts Medical School offers Career Pathways Communities which are peer learning groups that are themed by careers (e.g., public health, science communication). Over the course of three sessions, students and two industry professionals, who are the group's facilitators, meet to discuss attributes of careers, developing transferable skills during school, goal setting, and individual development plans [19]. When taken as a whole, commonalities emerge from these initiatives such as using individual development plans and developing job search skills and strategies. These are important pedagogical and curricular insights that should be considered when developing high intensity learning experiences for graduate students.

This paper presents an example of a high intensity, professional preparation initiative, The OPTIONS Program (Opportunities for PhDs: Transitions, Industry Options, Networking and Skills) at U of T, for PhDs and post-doctoral fellows. In particular, it discusses the program's development, evaluation, findings, and recommendations. With this paper, we intend to increase our understanding and contribute to the discussion of effective practices to prepare engineering graduate students for diverse careers.

\section{Context}

The FASE at $\mathrm{U}$ of $\mathrm{T}$ is home to 2415 graduate students, including $846 \mathrm{PhD}$ students. The number of engineering $\mathrm{PhDs}$ graduating has increased from $47 \mathrm{PhDs}$ per year in 2000 to $152 \mathrm{PhDs}$ per year in 2015. A recent study by U of T's School of Graduate Studies found that $26 \%$ of engineering $\mathrm{PhD}$ alumni are employed in tenure-track positions, $18 \%$ in other post-secondary education roles (e.g., research associate, adjunct professor), and 55\% outside the academy [3]. The latter group find employment within and outside Canada in many sectors including finance, government, research and development, manufacturing, and sales. In late 2016, FASE's Vice Dean, Graduate Studies and the Troost Institute for Leadership Education in Engineering (Troost ILead) began conversations to develop a professional development initiative to prepare PhDs and post-doctoral fellows for non-academic careers. Troost ILead provides curricular and cocurricular experiences to inspire engineers to develop their leadership potential. Its vision is "engineers leading change to build a better world".

\section{Program Development}

To assess the needs and wants of PhD students for a professional development initiative, in January 2017 we conducted a survey and held an exploratory session. The survey evaluated the engineering community's perception of career-ready skills, concerns about the school-to-work transition, and the format of a professional development initiative. We administered the survey to 110 graduate students that self-selected to attend a Faculty-wide, $\mathrm{PhD}$-alumni panel. The exploratory session was a venue to explore ideas and solicit feedback on professional development initiatives. It was attended by 27 graduate students, post-doctoral fellows, staff, faculty, and alumni that are involved in supporting the success of graduate students.

Following the survey and exploratory session, we formed a working group to produce a plan for a professional development initiative. The working group consisted of four faculty, one communication course instructor, one leadership educator, one career educator, and an external 
career management professional. Between March and August 2017, we ran eight prototype workshops to test programming ideas and stimulate interest in our program. Prototype workshops included: an alumni panel, LinkedIn, informational interviews, networking, and skills inventory sessions. There were 499 attendees at these offerings.

Following the success of the prototype workshops, we launched The OPTIONS Program, an eleven-week, application-based, Cohort Program for $30 \mathrm{PhDs}$ and post-doctoral fellows. In addition, we host approximately six Complementary Events throughout the academic year open to all $\mathrm{PhDs}$ and post-doctoral fellows. To develop the program, we employed backwards design, which is a method where you start designing from the desired result (i.e., what should participants learn by the end of the program) [20]. We began by identifying four learning goals or what we want the program to achieve: 1) inform students about the realities of the labour market; 2) raise the profile of professional development in FASE; 3) cultivate students' selfdirection and self-awareness; and 4) foster relationships between current students and $\mathrm{PhD}$ alumni employed outside the professoriate. We then created a list of knowledge and skills that aligned with each learning goal. Following this, we generated program learning outcomes, structure and framework, learning activities, and instructional strategies. The program is informed by adult and career learning theories and frameworks including Kolb's Experiential Learning Cycle [21], OneLifeTools/Career Cycles' evidence-based narrative assessment framework [22], planned happenstance [23], and U of T's Career Exploration and Education's Curriculum Framework [24].

\section{Program Description}

\section{Cohort Program}

We identified three learning outcomes for the Cohort Program: 1) reflect on strengths, desires, interests, and personal qualities to formulate an individual development plan; 2) communicate skills and experiences using job search strategies to highlight expertise and personal value; and 3) apply networking tools and labour market resources to identify and clarify career aspirations. These learning outcomes form the foundation of the program's three-pillar framework of reflect, communicate and apply (Figure. 1).

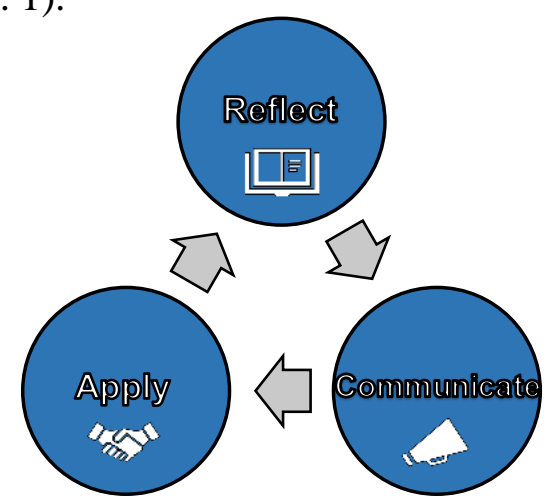

Figure 1. The Cohort Program's three-pillar framework which is based on the three learning outcomes of the program: 1) reflect on strengths, desires, interests, and personal qualities to formulate an individual development plan; 2) communicate skills and experiences using job search strategies to highlight expertise and personal value; and 3) apply networking tools and labour market resources to identify and clarify career aspirations. 
The program consists of weekly, two-hour sessions that take place over eleven weeks. In these sessions, which are facilitated by faculty and professional development staff, we cover career management topics including self-awareness, resumés, cover letters, personal pitches, and informational interviews (Table 1). The curriculum is tailored to an engineering graduate audience, through the use of discipline-specific language and examples. In addition to the eleven-week program, we invite participants to have two, one-on-one, thirty-minute meetings. The first meeting, which occurs midway through the program, is with a career coach who guides participants in debriefing their individual development plan (see more below) and setting goals for next steps. The second meeting, which occurs at the end of the program, is with an engineering professor to discuss and receive feedback on what the participant has learned about themselves and concerns about the school-to-work transition. We selected engineering professors who have industry experience and/or are involved in student success initiatives.

Table 1. The Cohort Program schedule. The program consists of weekly, two-hour sessions that take place over eleven weeks. In addition to the sessions, participants access an in-person and online individual development plan, work with a Peer Success Team, receive feedback on job search strategies, and participate in one-on-one, thirty-minute meetings (separately) with a career coach and engineering professor.

\begin{tabular}{|c|c|c|}
\hline $\begin{array}{l}\text { Program } \\
\text { Framework } \\
\text { Pillars }\end{array}$ & Session Topic & Additional Activities \\
\hline $\begin{array}{l}\text { Reflect } \\
\text { Apply }\end{array}$ & $\begin{array}{c}\text { You as a Professional I: } \\
\text { Labour Market and Transferable Skills }\end{array}$ & \\
\hline Reflect & You as a Professional II: Self-awareness & Form Peer Success Teams \\
\hline Reflect & Skills Inventory for Career Clarification I & $\begin{array}{l}\text { Access in-person individual } \\
\text { development plan }\end{array}$ \\
\hline $\begin{array}{l}\text { Reflect } \\
\text { Apply }\end{array}$ & Skills Inventory for Career Clarification II & $\begin{array}{l}\text { Access online individual } \\
\text { development plan }\end{array}$ \\
\hline $\begin{array}{l}\text { Reflect } \\
\text { Apply }\end{array}$ & $\begin{array}{l}\text { You as a Professional III: } \\
\text { Workplace Culture }\end{array}$ & $\begin{array}{l}\text { One-on-one meeting with } \\
\text { career coach }\end{array}$ \\
\hline Communicate & Networking I: Personal Value Proposition & \\
\hline Communicate & Networking II: LinkedIn & \\
\hline Communicate & Networking III: Informational Interviews & \\
\hline Communicate & $\begin{array}{l}\text { Job Search Strategies I: } \\
\text { Resumé and Cover Letter }\end{array}$ & $\begin{array}{l}\text { One-on-one feedback on } \\
\text { resumé and cover letter } \\
\text { through email }\end{array}$ \\
\hline Communicate & Job Search Strategies II: Interviewing & $\begin{array}{l}\text { One-on-one feedback on } \\
\text { interview skills during the } \\
\text { session }\end{array}$ \\
\hline $\begin{array}{l}\text { Reflect } \\
\text { Apply }\end{array}$ & Reflection and Next Steps & $\begin{array}{l}\text { One-on-one meeting with } \\
\text { engineering professor }\end{array}$ \\
\hline
\end{tabular}


Participants also receive one-on-one feedback on their resumés, cover letters, and interview skills. To foster peer-to-peer support, participants are placed into Peer Success Teams (groups of five). Participants are required to meet with their team at least once outside the program to get to know each other, complete in-class activities with their teams, provide feedback on their teammates' resumés, cover letters, and interview skills, and give a final presentation on their individual and team learning. We make the teams diverse by program, discipline of study, gender, and Bolton and Bolton Leadership Styles Inventory [25].

To provide a structure for self-awareness development and career exploration, we use an individual development plan. The two-part individual development plan, developed by OneLifeTools, utilizes narrative assessment to get participants to reflect on their stories in a systematic way. The first part, Who You Are Matters! A Career and Life Clarification Game, from here on called "in-person individual development plan", is a gamified experience where Peer Success Teams have a conversation to reflect on their strengths, desires, and personal qualities to generate three career possibilities and a goal to move a possibility forward. The second part, Online Storyteller, from here on called "online individual development plan", is a self-directed, narrative assessment where participants can reflect on their stories and experiences to formulate a career exploration plan [26].

To join the Cohort Program, participants must complete a short application and we select $30 \mathrm{PhD}$ and post-doctoral fellows based on the following criteria: third year and above (completed qualifying/comprehensive exams), strong interest in developing personal and professional skills, curious about diverse career options, eager to participate in group discussions, and willingness to support peer's career preparation. Prior to the start of the program, participants submit a $\$ 100$ deposit to confirm their commitment which is returned if they attend nine out of eleven sessions. Upon completion of the program, participants receive a certificate of completion and credit for $U$ of T's Graduate Professional Skills certificate.

We host two cohorts per academic year in the fall and winter semester. In total, we have had three cohorts with 26 participants in Cohort One in fall 2017, 30 participants in Cohort Two in winter 2018, and 30 participants in Cohort Three in fall 2019. We launched our fourth cohort in winter 2019.

In terms of resources, the development, coordination, and maintenance of the Cohort Program is led by one staff member with support from the working group. The program's sessions are led by a professor, communication course instructor, leadership educator, career educator, and external career management professional. One-on-one meetings are conducted by the external career management professional and four engineering professors.

\section{Complementary Events}

The goal of the complementary events is to provide the engineering graduate community with an introduction to the school-to-work transition. We accomplish this by hosting workshops on personal and professional skills (e.g., personal branding, interviewing, emotional intelligence), interacting with PhD alumni (e.g., panels, networking events), and visiting engineering organizations. Since September 2017, we have held 14 events with 707 attendees. These events are open to all $\mathrm{PhD}$ students and post-doctoral fellows, with some events open to thesis- and 
course-based master's students. We do not discuss the evaluations and findings from these events in this paper.

\section{Program Evaluation}

We administered an evaluation at the beginning of the first session (pre-evaluation) and end of the last session (post-evaluation). The evaluations evolved from cohort to cohort because of curriculum improvements and our desire to capture information we heard in conversations with participants. The evaluation was approved by the Research Ethics Board at the University of Toronto as a quality improvement project. Findings presented in this paper were not gained through research but rather a quality improvement project for The OPTIONS Program.

The pre-evaluation included demographic and information gathering questions (e.g., degreerelated work experience, extra-curricular/professional development activities). We do not present such data in this paper. The post-evaluation had four open-ended questions including: "What did you like about the program" and "What did you not like about the program?". The postevaluation also assessed the usefulness of activities to participant's career development on a four-point Likert Scale of one for Not Useful, two for Somewhat Useful, three for Useful, and four for Very Useful.

For Cohort Two and Three, we developed anonymous, pre-post indicators to assess participants' perception of the change in their skills and personal attributes. We had 21 indicators that we derived from overall program-level and session-level learning outcomes. Nineteen of the 21 indicators assessed participant's level of agreement of their confidence in their skills (e.g., "I can ask relevant questions in an informational interview to build rapport and learn about career sectors"), and two of the 21 indicators assessed participant's level of agreement in personal attributes (e.g., "I am optimistic about my career plans following my $\mathrm{PhD}$ or post-doctoral fellowship"). We measured responses on a five-point Likert Scale of one for Strongly Disagree, two for Disagree, three for Neither Agree nor Disagree, four for Agree, and five for Strongly Agree.

To analyze open-ended questions, we summarized data for all three cohorts and grouped the responses into themes. For usefulness of activities, we summarized data for all three cohorts. For pre-post indicators, we tested differences in participants' skills and personal attributes before and after the program using an ordinal logistic regression in JMP Pro 14 (SAS) [27]. We only present pre-post indicators from Cohort Three and not Cohort Two because the indicators slightly differ to reflect the evolution of the curriculum. For the skill indicators, we mapped each indicator to the Canadian Association for Graduate Studies' (CAGS) list of frequently occurring Transferable/Workplace Readiness Skills offered in graduate student professional development programming at Canadian universities [10]. We calculated percent change as the mean skill postevaluation subtract the mean skill pre-evaluation, divided by the mean skill post-evaluation.

\section{Findings}

Participants' Likes and Dislikes

When examining the responses to "What did you like about the program" from all three cohorts, four themes emerged. First, participants liked learning practical skills for the job search, for 
example, resumés and cover letter writing, interview skills, and LinkedIn. One participant said "For me the practical skills were most useful - cover letter, resumé, interview, etc... I really enjoyed working on these things as they seem to get neglected in graduate school." Second, participants liked the opportunity for self-reflection (i.e., who they are and how that connects to their career goals). One participant said "Gave me understanding of what actions I need to take to identify what I want to do as a professional and how to get a job..." Third, participants like the cohort-nature of the program where they can meet new people and find a community that shares the same concerns. One participant appreciated "The opportunity to meet other PhDs and postdocs who have the same concerns about job options." Another participant said "It provides a dedicated and safe environment for PhDs and post-docs to discuss their career possibilities and plans outside academia." And lastly, participants liked having a structure for career exploration (i.e., step-by-step process, dedicated time). One participant said "Good to do it from start to end it becomes a journey where all the small steps create a bigger picture."

When examining the responses to "What did you not like about the program" from all three cohorts, two themes emerged. First, some participants disliked the instructional strategy of small and large group discussions/activities because it made classes long and exhausting. We suspect participants, who are upper PhDs and post-doctoral fellows, may not have taken a class in a couple years or been exposed to experiential, active learning, instructional strategies. Second, some participants wanted the Peer Success Teams to be based on similar career goals. We intentionally avoided forming such homogeneous teams so participants were exposed to a diversity of thought rather than becoming stuck on one career trajectory.

Change in Participants' Confidence in Skill Indicators

We found a significant increase in participants' confidence in their skills after completing the program for 16 of the 19 skill indicators (Table 2). The greatest increases in skill indicators fall under CAGS' Transferable/Workplace Readiness Skills of career planning, informational interviews, and interviewing. For career planning, we found a 36\% increase in "I can create an actionable, career exploration plan to investigate three possible career options", and a $30 \%$ increase in "I can verbalize my goals and aspirations in a career statement". For informational interviews, we found a 33\% increase in "I can ask relevant questions in an informational interview to build rapport and learn about career sectors". For interviewing, we found a 33\% increase in "I can use strategies to succeed in different types of interview scenarios". Skill indicators related to CAGS' Transferable/Workplace Readiness Skills of career paths outside academia, self-assessment, and preparing a resumé/cover letter showed moderate changes of between 18 to $29 \%$. The lowest change in skill indicators were for CAGS' Transferable/Workplace Readiness Skills of networking and leadership/team building, ranging from 5 to $18 \%$.

Change in Participants' Personal Attributes Indicators

We found a significant increase in participants' confidence and optimism after completing the program (Table 3). Participants' confidence in their ability to implement a career exploration plan increased by $27 \%$, and participants' optimism about their career plans following their studies increased by $20 \%$. 
Table 2. Participants' change in confidence in their skills before $(\mathrm{N}=28)$ and after completing the program $(\mathrm{N}=25)$ for Cohort Three. Responses were measured on a five-point Likert Scale of one for Strongly Disagree, two for Disagree, three for Neither Agree nor Disagree, four for Agree, and five for Strongly Agree. Ordinal logistic regressions were used in all analyses. The Likelihood-ratio Chi Square is the test statistic. Significant relationships $(\mathrm{p}<0.05)$ are bolded. Skill indicators were mapped to the Canadian Association for Graduate Studies' (CAGS) list of frequently occurring Transferable/Workplace Readiness Skills offered in graduate student professional development programming at Canadian universities.

\begin{tabular}{|c|c|c|c|c|}
\hline \multirow{2}{*}{$\begin{array}{c}\text { CAGS' } \\
\text { Transferable / } \\
\text { Workplace } \\
\text { Readiness } \\
\text { Skills } \\
\end{array}$} & Skill Indicators & \multirow{2}{*}{$\begin{array}{l}\text { Likelihood- } \\
\text { ratio Chi } \\
\text { Square }\end{array}$} & \multirow{2}{*}{ p-value } & \multirow{2}{*}{$\begin{array}{c}\text { Percent } \\
\text { Change } \\
(\%)\end{array}$} \\
\hline & I am confident as of now... & & & \\
\hline Career planning & $\begin{array}{l}\text { I can create an actionable, career } \\
\text { exploration plan to investigate three } \\
\text { possible career options. }\end{array}$ & 29.79 & $<0.001$ & 36 \\
\hline $\begin{array}{l}\text { Informational } \\
\text { Interviews }\end{array}$ & $\begin{array}{l}\text { I can ask relevant questions in an } \\
\text { informational interview to build } \\
\text { rapport and learn about career } \\
\text { sectors. }\end{array}$ & 39.11 & $<0.001$ & 33 \\
\hline Interviewing & $\begin{array}{l}\text { I can use strategies to succeed in } \\
\text { different types of interview } \\
\text { scenarios. }\end{array}$ & 11.41 & $<0.05$ & 33 \\
\hline Career planning & $\begin{array}{l}\text { I can verbalize my goals and } \\
\text { aspirations in a career statement. }\end{array}$ & 33.73 & $<0.001$ & 30 \\
\hline $\begin{array}{l}\text { Career paths } \\
\text { outside } \\
\text { academia }\end{array}$ & $\begin{array}{l}\text { I can explain different types of } \\
\text { workplace cultures. }\end{array}$ & 29.80 & $<0.01$ & 29 \\
\hline Self-assessment & $\begin{array}{l}\text { I can explain my own leadership } \\
\text { style. }\end{array}$ & 32.12 & $<0.001$ & 26 \\
\hline Self-assessment & $\begin{array}{l}\text { I can identify and explain } \\
\text { transferable skills from } \mathrm{PhD} \\
\text { research to industry. }\end{array}$ & 26.85 & $<0.001$ & 26 \\
\hline Self-assessment & $\begin{array}{l}\text { I can explain which workplace } \\
\text { cultures align with my strengths and } \\
\text { desires. }\end{array}$ & 17.36 & $<0.01$ & 23 \\
\hline $\begin{array}{l}\text { Preparing a } \\
\text { resumé/cover } \\
\text { letter }\end{array}$ & $\begin{array}{l}\text { I can write an employment-oriented, } \\
\text { two-page cover letter. }\end{array}$ & 21.43 & $<0.001$ & 23 \\
\hline $\begin{array}{l}\text { Career paths } \\
\text { outside } \\
\text { academia }\end{array}$ & $\begin{array}{l}\text { I can describe the skills and } \\
\text { qualities employers seek in } \\
\text { prospective employees. }\end{array}$ & 22.17 & $<0.001$ & 22 \\
\hline $\begin{array}{l}\text { Preparing a } \\
\text { resumé/cover } \\
\text { letter }\end{array}$ & $\begin{array}{l}\text { I can write an employment-oriented, } \\
\text { two-page resumé. }\end{array}$ & 21.13 & $<0.001$ & 22 \\
\hline
\end{tabular}




\begin{tabular}{|c|c|c|c|c|}
\hline \multirow{2}{*}{$\begin{array}{c}\text { CAGS' } \\
\text { Transferable / } \\
\text { Workplace } \\
\text { Readiness } \\
\text { Skills }\end{array}$} & Skill Indicators & \multirow[b]{2}{*}{$\begin{array}{l}\text { Likelihood- } \\
\text { ratio Chi } \\
\text { Square }\end{array}$} & \multirow[b]{2}{*}{ p-value } & \multirow[b]{2}{*}{$\begin{array}{l}\text { Percent } \\
\text { Change } \\
(\%)\end{array}$} \\
\hline & I am confident as of now... & & & \\
\hline Interviewing & $\begin{array}{l}\text { I can answer different types of } \\
\text { interview questions in a persuasive } \\
\text { and relevant manner. }\end{array}$ & 11.41 & $<0.05$ & 21 \\
\hline Self-assessment & $\begin{array}{l}\text { I can clearly explain my strengths, } \\
\text { interests, personal qualities, and } \\
\text { assets. }\end{array}$ & 17.11 & $<0.001$ & 20 \\
\hline Networking & $\begin{array}{l}\text { I can locate online tools and } \\
\text { resources to find engineering } \\
\text { professionals that share career } \\
\text { interests with me. }\end{array}$ & 17.17 & $<0.01$ & 19 \\
\hline $\begin{array}{l}\text { Career paths } \\
\text { outside } \\
\text { academia }\end{array}$ & $\begin{array}{l}\text { I can identify sectors that employ } \\
\text { engineers }\end{array}$ & 14.25 & $<0.05$ & 18 \\
\hline Networking & $\begin{array}{l}\text { I can confidently introduce myself } \\
\text { to engineering professionals. }\end{array}$ & 7.19 & 0.13 & 18 \\
\hline $\begin{array}{l}\text { Leadership/team } \\
\text { building }\end{array}$ & $\begin{array}{l}\text { I can leverage my leadership style } \\
\text { to work in teams. }\end{array}$ & 11.30 & $<0.05$ & 17 \\
\hline Networking & $\begin{array}{l}\text { I can deliver technical talks to a } \\
\text { non-technical audience using clear, } \\
\text { accessible language. }\end{array}$ & 5.95 & 0.11 & 13 \\
\hline $\begin{array}{l}\text { Leadership/team } \\
\text { building }\end{array}$ & $\begin{array}{l}\text { I can effectively build working } \\
\text { relationships with others. }\end{array}$ & 4.25 & 0.12 & 5 \\
\hline
\end{tabular}

Table 3. Participants' agreement in their personal attributes before $(\mathrm{N}=28)$ and after completing the program $(\mathrm{N}=25)$ for Cohort Three. Responses were measured on a five-point Likert Scale of one for Strongly Disagree, two for Disagree, three for Neither Agree nor Disagree, four for Agree, and five for Strongly Agree. Ordinal logistic regressions were used in all analyses. The Likelihood-ratio Chi Square is the test statistic. Significant relationships $(\mathrm{p}<0.05)$ are bolded.

\begin{tabular}{|l|c|c|c|}
\hline \multicolumn{1}{|c|}{ Personal Attribute Indicators } & $\begin{array}{c}\text { Likelihood- } \\
\text { ratio Chi } \\
\text { Square }\end{array}$ & p-value & $\begin{array}{c}\text { Percent } \\
\text { Change } \\
(\mathbf{\%})\end{array}$ \\
\hline $\begin{array}{l}\text { I am confident in my ability to implement a career } \\
\text { exploration plan that is aligned with my aspirations. }\end{array}$ & 28.84 & $<\mathbf{0 . 0 1}$ & 27 \\
\hline $\begin{array}{l}\text { I am optimistic about my career plans following my } \\
\text { PhD or post-doc. }\end{array}$ & 13.37 & $<\mathbf{0 . 0 0 1}$ & 20 \\
\hline
\end{tabular}


Usefulness of Learning Activities

Overall, the majority of participants found the learning activities useful and very useful (Figure 2). We found that learning activities rated "highly useful" involved feedback (from an instructor or peer) and had a practical, immediate benefit. One hundred percent of participants deemed developing a resumé and cover letter useful to highly useful. In this activity, participants generated application material to a current job posting, and an instructor and their Peer Success Teams provided feedback. Similarly, $100 \%$ of participants rated meeting with a professor useful to highly useful. In this activity, participants had a conversation on their self- and careerdevelopment, as well as received tips to move their career exploration plan forward. We also found, that $98 \%$ of participants deemed generating informational interview questions as useful to highly useful. In this activity, participants received feedback from the instructor and their peers to generate and refine a database of questions. Likewise, $98 \%$ of participants rated the debrief of the online individual development plan with a career coach as useful to highly useful. In this activity, participants clarified career possibilities and set actionable goals to explore possibilities. Lastly, $97 \%$ of participants deemed the practice interviewing activity as useful to highly useful. In this activity, each Peer Success Team was assigned an instructor who asked interview questions and provided feedback. We found learning activities rated "less useful" involved selfassessment inventories (e.g., Bolton and Bolton Leadership Styles Inventory), Peer Success Teams, and sessions that were primarily lecture and group discussions. 


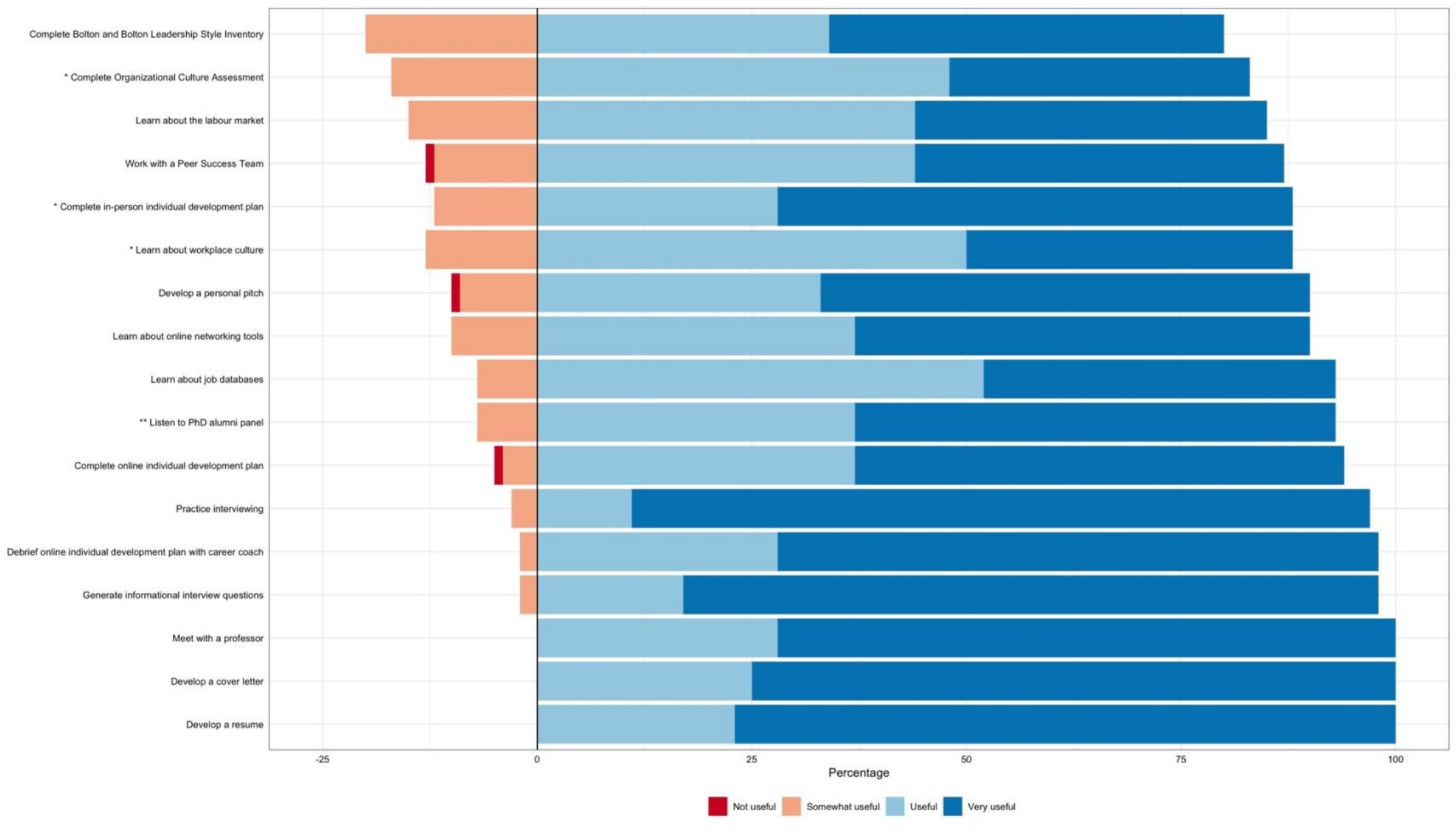

Figure 2. Participants' rating of the useful of learning activities to their career development for Cohort One $(\mathrm{N}=23)$, Cohort Two $(\mathrm{N}=$ 26), and Cohort Three $(\mathrm{N}=25)$. Learning activities denoted with an * were only measured in Cohort Three and $* *$ were only measured in Cohort One and Two due curriculum changes. Responses were measured on a four-point Likert Scale of one for Not useful, two for Somewhat Useful, three for Useful, and four for Very Useful. 


\section{Discussion, Recommendations, and Next Steps}

All in all, some key takeaways emerge from our findings. Firstly, career development and professional skills training foster participants who are more confident and optimistic about their future. Secondly, participants need a dedicated time, space, and systematic process to launch their career exploration with a community of like-minded individuals. As the culture of academia still places high value on producing professors, the Cohort Program provides a venue to discuss a variety of professional endeavours. The cohort nature of this program promotes relationship building, as well as smaller interactions through the Peer Success Teams, one-on-one meetings, and feedback. Thirdly, participants appreciate the opportunity to reflect on their strengths, desires, and personal qualities to generate an individual development plan. As engineering graduate degrees are highly technical and focused on discipline-specific knowledge, we suspect participants have little to no opportunity to self-reflect and create a career exploration plan. Providing a structured tool, like an individual development plan, creates an organized process for self-awareness development and career planning. Finally, although we find most skills and learning activities well-received, those that involve a practical, immediate benefit (e.g., resumés and cover letter writing, interview skills) are very popular among participants.

These findings highlight essential elements we recommend engineering educators incorporate in career planning and professional skills training. Specific to their unique needs, $\mathrm{PhDs}$ benefit from programming that helps them transform the higher level constellation of their subject matter expertise, research skills, and analysis skills into transferable skills language and newlygenerated career possibilities beyond the over-simplified notion commonly stated as, "a job in industry". Educators can use self-awareness development tools (e.g., Bolton and Bolton Leadership Styles Inventory, narrative assessment) to support PhDs in clarifying their skills and strengths, and then a process, such as an individual development plan, to organize and connect their new self-knowledge to career aspirations and goals. To support $\mathrm{PhDs}$ to experiment with potential career pathways, educators should share informational interviewing tools and resources so $\mathrm{PhDs}$ can have conversations with industry professionals. Also, educators should encourage $\mathrm{PhDs}$ to take action by developing and practicing job search strategies (e.g., interviewing, resumés, cover letters), with opportunities for feedback and iteration. Above all, educators should create spaces for PhDs to have career conversations and network with their peers.

Moving forward, our plan is to continue offering The OPTIONS Program, both the Cohort Program and Complementary Events. We also maintain an active LinkedIn group where all four cohorts can interact and share resources, as well as host an annual OPTIONS reunion to bring together all cohorts. In the long term, we intend to follow-up with participants through a formal evaluation to track behaviour changes, employment outcomes, and re-assess the usefulness of program activities. This will provide insight into which learning activities are most impactful for students attaining their personal and career goals. Our ultimate intention is to encourage conversations on diverse career options, build relationships and networks within the engineering community, and inspire PhDs to embrace and navigate the continuous, lifelong process of personal exploration and career clarification. 


\section{References}

[1] J. Edge, and D. Munro, Inside and Outside the Academy: Valuing and Preparing PhDs for Careers. Ottawa, ON: The Conference Board of Canada, 2015. pp. 22, 54-66.

[2] L. Jonker, Ontario's PhD Graduates From 2009: Where Are They Now?. Higher Education Quality Council of Ontario, 2016. pp. 15-16, 24.

[3] University of Toronto, "10,000 PhDs Project," School of Graduate Studies, 2017. [Online]. Available: http://www.sgs.utoronto.ca/data/Pages/employment-outcomes.aspx [Accessed: Jan 31, 2019].

[4] M. Fiegener, "Number of Doctorates Awarded Continue to Grow in 2009: Indicators of Employment Outcomes Mixed," National Science Foundation, NSF 11-305, Nov 2010. [Online]. Available: https://www.nsf.gov/statistics/infbrief/nsf11305/ [Accessed: Oct 9, 2018].

[5] M. Roach, and H. Sauermann, "A taste for science? PhD scientists' academic orientation and self-selection into research careers in industry," Research Policy, vol. 39, pp. 422434, 2010.

[6] M. Roach, and H. Sauermann, "The declining interest in an academic career," Plos One, vol. 12, no. 9, pp. 1-23, 2017.

[7] D. Cyranoski, N. Gilbert, H. Ledford, A. Nayar, and M. Yahi, “The PhD factory,” Nature, vol. 472, pp. 276-279, 2011.

[8] National Academies of Sciences, Engineering, and Medicine, Graduate STEM Education in the 21st Century, Washington, DC: The National Academies Press, 2018.

[9] D. Denecke, K. Feaster, and K. Stone, Professional Development: Shaping Effective Programs for STEM Graduate Students, Washington, DC: Council of Graduate Schools, 2017.

[10] M. Rose, Graduate Student Professional Development: A Survey with Recommendations, St. Catherines, ON: Canadian Association for Graduate Studies, 2012. pp. 17-18.

[11] University of Toronto, "University of Toronto Graduate Engineering Career Fair," Faculty of Applied Science and Engineering, 2018. [Online]. Available:

uoft.me/GECF2019 [Accessed: Jan 31, 2019].

[12] University of Alberta. "Graduate Studies Professional Development," Faculty of Engineering. [Online]. https://www.ualberta.ca/engineering/student-services/academicsupport/graduate-studies-professional-development [Accessed: Feb 1, 2019].

[13] University of British Columbia. "UBC PhD Career Outcome Survey 2016," Graduate \& Postdoctoral Studies. [Online]. Available: http://outcomes.grad.ubc.ca/ [Accessed: Feb 1, 2019].

[14] Queen's University. "Welcome to the Queen's Grad Maps," Career Sevices. [Online]. Available: https://careers.queensu.ca/gradmaps [Accessed: Feb 1, 2019].

[15] H. Lee, M. Miozzo, and P. Laredo, "Career patterns and competences of PhDs in science and engineering in the knowledge economy: The case of graduates from a UK researchbased university," Research Policy, vol. 39, pp. 869-881, 2010.

[16] M. Sinche, R. L. Layton, P. D. Brandt, A. B. O'Connell, J. D. Hall, A. M. Freeman, J. R. Harrell, J. G. Cook, and P. J. Brennwald, "An evidence-based evaluation of transferrable skills and job satisfaction for science PhDs," Plos One, vol. 12, no. 9, pp. 1-16, 2017.

[17] N. Lee, and R. Reithmeier, "A Graduate Course in Professional Development," Science. [Online]. Available: https://www.sciencemag.org/careers/2013/10/graduate-courseprofessional-development [Accessed: Mar 8, 2019]. 
[18] J. Branan, X. Li, and R. Wheeler, "Building a career planning course for STEM PhDs," Nature Biotechnology, vol. 36, no. 12, pp. 1217-1219, 2018.

[19] University of Massachusetts Medical School, "Career Pathways Communities," Center for Biomedical Career Development. [Online]. Available:

https://www.umassmed.edu/gsbs/career/pathways/overview/community/ [Accessed: Mar 8, 2019].

[20] J. Richards and D. Ashbourne, A Guide to Curriculum Renewal at the University of Toronto, Toronto, ON: University of Toronto, 2017.

[21] D. Kolb, Experiential Learning: Experiences as the Source of Learning, Englewood Cliffs, NJ: Prentice-Hall, 1984.

[22] M. Franklin B. Yanar, and R. Feller, "Narrative method of practice increases curiosity \& exploration, psychological capital, and personal growth leading to career clarity: A retrospective outcome-study," Canadian Journal of Career Development, vol. 14, no. 2, pp. 12-23, 2015.

[23] K. E. Mitchell, A. S. Levin, and J. D. Krumboltz, "Planned happenstance: Constructing unexpected career opportunities," Journal of Counseling and Development, vol. 77, no. 2, pp. 115-124, 1999.

[24] K. McCrank, K. Archibald, J. Turner, K. Bowers, and M. Giamos, University of Toronto's Career Exploration \& Education's Curriculum Framework, Toronto, ON: University of Toronto, 2018.

[25] R. Bolton and D. Grover Bolton, People Styles at Work and Beyond (Second Edition), New York, NY: American Management Association, 2009.

[26] M. Franklin, T. Botelho, and B. Graham, "Clarification through storytelling and storylistening using Onelifetools/Career Cycles Narrative Assessment System," Career Development Network Journal, vol. 33, no. 4, pp. 57-70, 2017.

[27] JMP, Version 14. SAS Institute Inc., Cary, NC, 1989-2019. 